\title{
Article
}

\section{Potential use of Kebilian clay reserves (southern Tunisia) for the production of geopolymer materials}

\author{
Chedlia Ounissi ${ }^{\star \star}$ (D), Salah Mahmoudi ${ }^{1}$, Luca Valentini², Ali Bennour ${ }^{3}$, Enrico Garbin ${ }^{4}$, Gilberto Artioli² \\ and Mabrouk Montacer ${ }^{1}$ \\ ${ }^{1}$ Research Unity of Geo-systems, Geo-resources and Geo-environments (UR3G), Department of Earth Sciences, Faculty of Sciences of Gabes, University of Gabes, \\ 6072, Zrig, Gabes, Tunisia; ${ }^{2}$ Departement of Geosciences - Center CIRCe, University of Padua, via Gradenigo 6, Padua, Italy; Institute of Arid Regions (IRA), Medenine \\ 4100, Tunisia and ${ }^{4}$ Department of Civil, Architectural and Environmental Engineering, University of Padua, via Gradenigo 6, 35131, Padua, Italy
}

\begin{abstract}
The aim of this study was to help drive the Tunisian construction industry towards a more sustainable approach given the existence of abundant local raw material deposits that could be exploited for the production of low- $\mathrm{CO}_{2}$ binders. Various clay sediments from the Kebili region (southern Tunisia) were characterized by chemical analysis, X-ray diffraction, thermal analysis and geotechnical tests to determine their suitability for the preparation of geopolymer binders. The clays consist of illite and kaolinite with other accessory minerals. To test the possibility of using these materials as precursors for the production of low- $\mathrm{CO}_{2}$ and low-cost geopolymers, the raw samples were calcined and activated by addition of solid sodium silicate. Compressive strength tests performed on four alkali-activated clays show that promising mechanical performance may be achieved, with mechanical strength values as high as $25 \mathrm{MPa}$ after 7 days, depending on the clay composition. The mechanical strength is related to the $\mathrm{SiO}_{2}: \mathrm{Al}_{2} \mathrm{O}_{3}$ and $\mathrm{Al}_{2} \mathrm{O}_{3}:\left(\mathrm{NaO}_{2}+\mathrm{K}_{2} \mathrm{O}\right)$ ratios. Careful selection of the raw materials is, therefore, an essential step in the exploitation of clay deposits to be used for the production of ecological materials such as geopolymers.
\end{abstract}

Keywords: alkali activation, clay characterization, geopolymer, Kebili, Tunisia

(Received 28 November 2019; revised 23 April 2020; Accepted Manuscript online: 6 May 2020; Associate Editor: Joao Labrincha)

The term 'geopolymers' was first introduced by Glukovsky (1959) and later used by Davidovits (1988) to describe binders produced from aluminosilicate materials (Liebau, 1985), such as clays and feldspars, or industrial waste products, such as coal fly ash and metallic blast furnace slag (Xu \& van Deventer, 2003; Brew \& MacKenzie, 2007).

There has been significant recent interest in geopolymers because of their physical properties such as high mechanical strength (Zhang et al., 2010; Ding et al., 2016), resistance to heat (Fernández-Jiménez et al., 2010), anti-corrosion properties (Cui et al., 2008; Babaee \& Castel, 2016) and their potential to reduce energy and carbon emissions (Diop \& Grutzeck, 2008; MacKenzie, 2009; Davidovits, 2011; Provis, 2014; Chakraborty, 2014).

Clays, being natural aluminosilicates, are useful as raw materials in various industrial sectors, and they can be used both as supplementary cementitious materials (e.g. Carvalho et al., 2008; Fernandez et al., 2011; Tironi et al., 2013; Garg \& Skibsted, 2014; Hollanders et al., 2016) and as primary aluminosilicate precursors in alkali activation, which may be a sustainable alternative to Portland cement (Reig et al., 2013; Marsh et al., 2018).

The most common clay material used for geopolymers is dehydroxylated kaolin, known as metakaolin (Duxson et al., 2007;

${ }^{*}$ E-mail: ounissichadlia@yahoo.ca

Cite this article: Ounissi C, Mahmoudi S, Valentini L, Bennour A, Garbin E, Artioli G Montacer M (2020). Potential use of Kebilian clay reserves (southern Tunisia) for the production of geopolymer materials. Clay Minerals 55, 101-111. https://doi.org/10.1180/ clm.2020.14
Hounsi et al., 2013; Shaqour et al., 2017). Less frequently, 2:1 dioctaheral-layer silicates such as illite, smectite or even interstratified illite-smectite may be used for the production of these binders. Common clays are abundant and well distributed worldwide in soils; therefore, they represent a valid and cheap raw material for the production of sustainable binders.

This work examines the potential of an illite-kaolinite-rich clay to be used as a low-carbon binder after alkali activation. The studied clays of Lower Cretaceous age (Hauterivian-Barremian) are widely exposed in the region of Kebili (southern Tunisia).

\section{Geological setting}

Tunisia is particularly rich in sedimentary deposits that may be exploited for construction purposes. Numerous studies have been carried out on the valorization of natural clay reserves in ceramic and chemical industries throughout the country (e.g. Hajjaji et al., 2010; Bennour et al., 2015a, 2015b; Hammami-Ben Zaied et al., 2015; Selmani et al., 2015; Mahmoudi et al., 2016; M'barek-Jemaï et al., 2017; Anis et al., 2019; Mkaouar et al., 2019), but few studies have focused on the southern range of the Chotts zone.

The study area corresponds to the convergence of several structural domains in southern Tunisia. It is bounded to the north by the Southern Atlas, to the east by the coastal Jeffara plain and to the south by the platfoxrm of Daher and the Tebaga chain of Kebili (Fig. 1).

During the Cretaceous, the Chotts zone, particularly the southern range and the eastern part of the north range, was a 

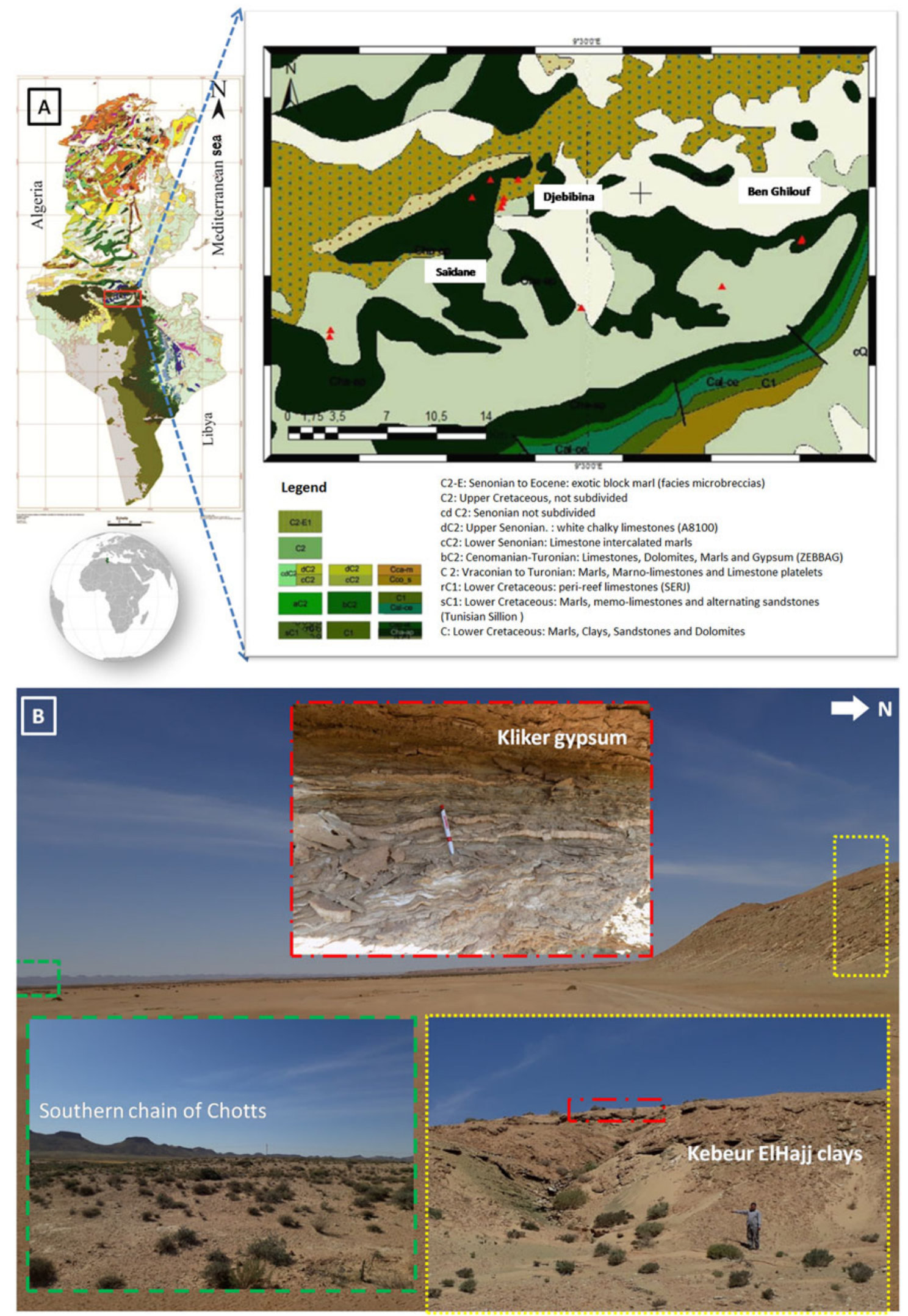

Fig. 1. (a) Location of the studied area (triangle symbol: sampling points), (b) Panoramic view of the area. 
site of tectonic activity that controlled sedimentation in this basin (Abbes \& Tlig, 1991). Thus, the southern chain of the Chotts zone corresponds to a monoclinal set of approximately east-west direction, sloping at $30-40^{\circ}$ towards the south (Ghanmi \& Potfaj, 1991). It consists of an alignment of Cretaceous ridges that extend for $\sim 100 \mathrm{~km}$ from the El Hamma region to Kebili (Ghanmi \& Potfaj, 1991).

Previous work on the stratigraphic series of the basin of the Chotts zone (e.g. Rabia, 1984; Ben Youssef \& Peybernes, 1986) increased brought stratigraphic precision in the Lower Cretaceous (Barremian-Albian). The zone of interest corresponds to the Bouhedma and Sidi Aîch Formations of Barremian age, which comprise six lithostratigraphic units: from the base to the top, Ben Ghilouf, Doukhane, Kebeur ElHajj, Kliker, Berada and SidiAîch (Ghanmi \& Potfaj, 1987). All of these formations are composed of an alternation of gypsum, clays, sandstones and carbonates with silicified wood. The thickness of the Barremian series varies from $\sim 350 \mathrm{~m}$ in the region of Tebaga Kebili (Oued el Guetar) in the south to $\sim 800 \mathrm{~m}$ in the region of Bir Rekeb (Oued Tmirina) in the north (Abbes \& Tlig, 1991).

\section{Experimental methods and material characterization}

$\mathrm{X}$-ray diffraction (XRD) measurements were performed using a Panalytical X'Pert Pro diffractometer equipped with a Co anode $\mathrm{X}$-ray tube $(40 \mathrm{kV}, 40 \mathrm{~mA})$, a Bragg-Brentano ${ }^{\mathrm{HD}}$ optical module and an X'Celerator detector (with a detection length of $2.122^{\circ} 2 \theta$ ). The divergence slit was fixed at $1 / 4^{\circ}$, primary and secondary Soller slits were fixed at $0.04 \mathrm{rad}$ and a spinning sample holder $(27 \mathrm{~mm}$ diameter) was adopted to obtain optimum particle statistics.

The samples were back-loaded into the sample holders, and diffraction patterns were collected in the $3-85^{\circ} 2 \theta$ range, with a $0.02^{\circ} 2 \theta$ step size, counting an equivalent time of $100 \mathrm{~s}$ per step. Quantitative phase analysis was performed using the Rietveld method.

Atomic absorption spectroscopy was used for the determination of the major element composition. The loss on ignition was evaluated from the weight difference between samples heated at $100^{\circ} \mathrm{C}$ and $1000^{\circ} \mathrm{C}$ for $2 \mathrm{~h}$. The results are expressed in percentage concentration of oxides. The specific surface area was used to record the clay-fraction activity, and it was determined with the methylene blue index method. A total of $10 \mathrm{~g}$ of powdered clay was dispersed in $100 \mathrm{~mL}$ of distilled water and mixed with the methylene blue solution $\left(10 \mathrm{~g} \mathrm{~L}^{-1}\right)$ (Sivapullaiah et al., 2008). One drop of this suspension was placed on filter paper, and the specific surface was determined from the amount of adsorbed methylene blue (Ferrari \& Gualtieri, 2006).

The Atterberg limits were determined using the Casagrande method (LCPC, 1987; Grabowska-Olszewska, 2003) with an experimental error of \pm 3 SD. The grain-size distribution was obtained by wet granulometric analysis. Micro-size analysis was performed by sedimentation in a Micromeritics SediGraph 5120 particle-size analyser in the size range $0.1-300 \mu \mathrm{m}$. Compressive strength tests were performed on hardened alkali-activated samples consisting of prisms of $1.5 \mathrm{~cm}$ in diameter and $6.0 \mathrm{~cm}$ in height using a Sun 2500 universal benchtop testing machine (Galdabini, Varese, Italy), with a full-scale of $2500 \mathrm{~N}$ and an accuracy of $0.03 \%$.

Fourier-transform infrared (FTIR) spectra of the studied clays were obtained using the $\mathrm{KBr}$ pellet technique with a Perkin Elmer 783 FTIR spectrometer in the range $4000-400 \mathrm{~cm}^{-1}$. Scanning electron microscopy (SEM) images were obtained on polished sections to observe the microstructure of the reacted samples using a CamScan MX3000 (Applied Beams, Beaverton, OR, USA). Thermal analysis was performed using a Mettler Toledo TGA/DSC 3+ thermal analyser (Zurich, Switzerland) in static air and from room temperature up to $1200^{\circ} \mathrm{C}$ with a temperature ramp of $10^{\circ} \mathrm{C} \mathrm{min}^{-1}$.

Semi-adiabatic calorimetry was carried out using Omega (Norwalk, CT, USA) thermocouples and Styrofoam containers with a measured coefficient of heat loss of $25 \mathrm{~mJ} \mathrm{~K}^{-1} \mathrm{~s}^{-1}$.

\section{Clay sampling and characterization}

Clay samples were collected from the base of the Lower Cretaceous series (Hauterivian-Barremian) in widely exposed outcrops in the region of Kebili (southern Tunisia). Figure 2 shows the alternation of red, green and yellow clays with the intercalation of other lithologies, including gypsum, marl and sandstone. Forty-five samples were collected from each level. These samples were blended and quartered to ensure representability and labelled Cr1, Dj1, C2 and BM2 for laboratory assessment, including identification of clay properties and behaviour upon alkali activation.

The chemical compositions of the raw samples are reported in Table 1. The samples are characterized by $\mathrm{SiO}_{2}$ contents in the range $47-56 \%$ and $\mathrm{Al}_{2} \mathrm{O}_{3}$ contents in the range $13-18 \%$. The $\mathrm{Al}_{2} \mathrm{O}_{3}: \mathrm{SiO}_{2}$ ratio is close to the minimal optimum value $(0.3)$ for clay reactivity in cement systems (Alujas Diaz, pers. comm.), except for sample $\mathrm{Dj} 1$, for which the $\mathrm{Al}_{2} \mathrm{O}_{3}: \mathrm{SiO}_{2}$ ratio was 0.2 . The average alkali content $\left(\mathrm{K}_{2} \mathrm{O}+\mathrm{Na}_{2} \mathrm{O}\right)$ is $5.4 \%$. Generally, alkalis in clays reduce their refractory characteristics. The loss on ignition varies between $9 \%$ and $13 \%$ due to carbonate decomposition clay mineral dihydroxylation and sulfur decomposition (Nayak \& Singh, 2007; Celik, 2010; Boussen et al., 2016; Mahmoudi et al., 2016).

The mineralogical composition of the samples is listed in Table 2. The clay mineral content exceeds $50 \%$ in all samples. Illite is the dominant clay mineral and kaolinite is present in smaller amounts (illite:kaolinite ratio $\approx 4: 1$ ). All samples contain significant amounts of quartz. Carbonate phases (dolomite and/or calcite) are present in all samples except Cr1. Significant amounts of gypsum are present in sample $\mathrm{Dj} 1$. Iron oxides are detected in Cr1 and Dj1.

The grain-size distribution of representative samples, obtained by laser scattering, revealed a predominance of the silt fraction $(2-20 \mu \mathrm{m})$. This fine fraction is acceptable for geopolymer synthesis (Allahverdi \& Kani, 2009; Merabtene et al., 2019). Figure 3 shows the particle-size distribution curve of the $\mathrm{C} 2$ sample.

The relatively low values of specific surface area $\left(38 \mathrm{~m}^{2} \mathrm{~g}^{-1}\right)$, determined using the methylene blue index method, are consistent with the lack of expansible clay minerals and the existence of abundant non-clay minerals (i.e. quartz, calcite). Plasticity measurements showed a moderate plasticity index (Fig. 4).

The FTIR spectra of the samples are typical of phyllosilicates (Srasra et al., 1994; Madejová, 2003), with bands at $3620 \mathrm{~cm}^{-1}$ attributed to octahedral $\mathrm{OH}$-stretching in illite and the inner hydroxyls of kaolinite (Fig. 5). The stretch band at $3693 \mathrm{~cm}^{-1}$ corresponds to the inner surface octahedral $\mathrm{OH}$ of kaolinite. The bands close to 1635 and $1425 \mathrm{~cm}^{-1}$ indicate water and carbonates, respectively (Petit, 2006). Bands in the low-frequency range $\left(1200-900 \mathrm{~cm}^{-1}\right)$ are associated with the presence of quartz, especially those at 1030 and $915 \mathrm{~cm}^{-1}$, and clay minerals. Quartz, 
Fig. 2. Photograph of red-yellow-green superposed clays from the Kebili region (Lower Cretaceous).

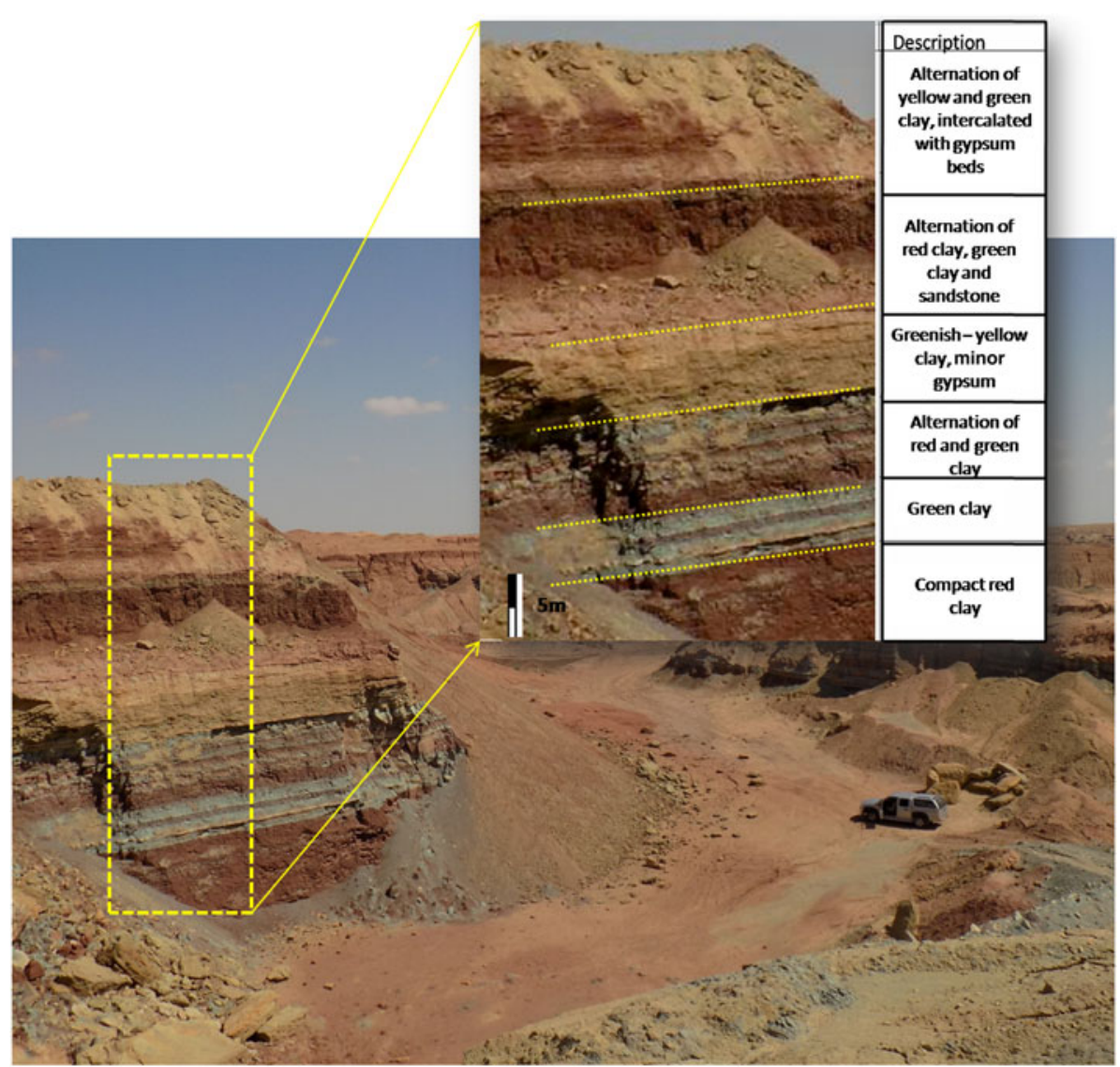

Table 1. Chemical composition (wt.\%) of the raw materials.

\begin{tabular}{lccccccccc}
\hline Samples & $\mathrm{LOI}\left(1000^{\circ} \mathrm{C}\right)$ & $\mathrm{SiO}_{2}$ & $\mathrm{Al}_{2} \mathrm{O}_{3}$ & $\mathrm{CaO}$ & $\mathrm{MgO}$ & $\mathrm{Fe}_{2} \mathrm{O}_{3}$ & $\mathrm{Na}_{2} \mathrm{O}$ & $\mathrm{K}_{2} \mathrm{O}$ & $\mathrm{SO}_{3}$ \\
\hline $\mathrm{C} 2$ & 9.7 & 53.4 & 17.9 & 2.8 & 2.3 & 6.7 & 0.4 & 4.1 & 1.1 \\
$\mathrm{Cr} 1$ & 11.4 & 52.6 & 18.0 & 0.6 & 2.0 & 7.4 & 0.2 & 4.8 & 1.0 \\
$\mathrm{BM} 2$ & 13.5 & 48.9 & 15.6 & 6.0 & 1.7 & 6.5 & 0.4 & 4.5 & 1.5 \\
$\mathrm{Dj} 1$ & 10.0 & 54.8 & 13.6 & 4.5 & 1.1 & 6.2 & 0.8 & 3.9 & 4.0 \\
\hline
\end{tabular}

The analytical error is $\pm 2 \%$.

$\mathrm{LOI}=$ loss on ignition.

present to significant extents in all of the samples, also presents two other characteristic bands at 800 and $781 \mathrm{~cm}^{-1}$ (Farmer, 1974; Hajjaji et al., 2001, cited in Sdiri et al., 2010). A large band at $1032 \mathrm{~cm}^{-1}$ is attributed to $\mathrm{Si}-\mathrm{O}-\mathrm{Si}$ of the clay minerals (Handke \& Mozgawa, 1993; Mozgawa et al., 1999).

The band at $471 \mathrm{~cm}^{-1}$ is attributed to $\mathrm{Si}-\mathrm{O}-\mathrm{Mg}$ bending (van der Marel \& Beutelspacher, 1976). The $\mathrm{C}=\mathrm{O}$ elongation vibration was recorded at $1720 \mathrm{~cm}^{-1}$ (Guo \& Rockstraw, 2006). The FTIR results obtained are in agreement with the chemical and mineralogical results mentioned earlier in the text.

A representative differential scanning calorimetry (DSC)/ thermogravimetric analysis (TGA) curve of the C2 sample is displayed in Fig. 6 . The first endothermic peak at $180^{\circ} \mathrm{C}$ corresponds to the removal of adsorbed water, with a total loss of mass of $5.2 \%$. A second exothermic peak appears at $425^{\circ} \mathrm{C}$, which corresponds to the decomposition of organic matter with a mass loss of $3.8 \%$ (Mahmoudi et al., 2016). A third endothermic peak is detected at $720^{\circ} \mathrm{C}$, corresponding to decarbonation and associated with a mass loss of $\sim 4.5 \%$. Previous thermal analyses performed on clays containing kaolinite and illite provided similar results (Bennour et al., 2015b).

\section{Binder preparation and testing}

The clay samples were dried in an oven at $80^{\circ} \mathrm{C}$ prior to grinding. Calcination was then carried out in an electric furnace at $800^{\circ} \mathrm{C}$

Table 2. Mineralogical composition (wt.\%) of the raw materials.

\begin{tabular}{|c|c|c|c|c|c|c|c|c|}
\hline \multirow[b]{2}{*}{ Samples } & \multirow[b]{2}{*}{ Quartz } & \multirow[b]{2}{*}{ Calcite } & \multirow[b]{2}{*}{ Dolomite } & \multirow[b]{2}{*}{ Hematite } & \multirow[b]{2}{*}{ Gypsum } & \multirow[b]{2}{*}{ Phyllosilicate } & \multicolumn{2}{|c|}{ Fraction $(<2 \mu \mathrm{m})$} \\
\hline & & & & & & & Illite & Kaolinite \\
\hline $\mathrm{C} 2$ & 21 & _- & 18 & _ & _ & 61 & 77 & 23 \\
\hline $\mathrm{Cr} 1$ & 23 & - & _ & 4 & - & 73 & 80 & 20 \\
\hline BM2 & 29 & 11 & 4 & - & - & 56 & 82 & 18 \\
\hline Dj1 & 33 & 4 & _- & $\overline{1}$ & $1 \overline{2}$ & 51 & 82 & 18 \\
\hline
\end{tabular}

The analytical error is $\pm 5 \%$. 


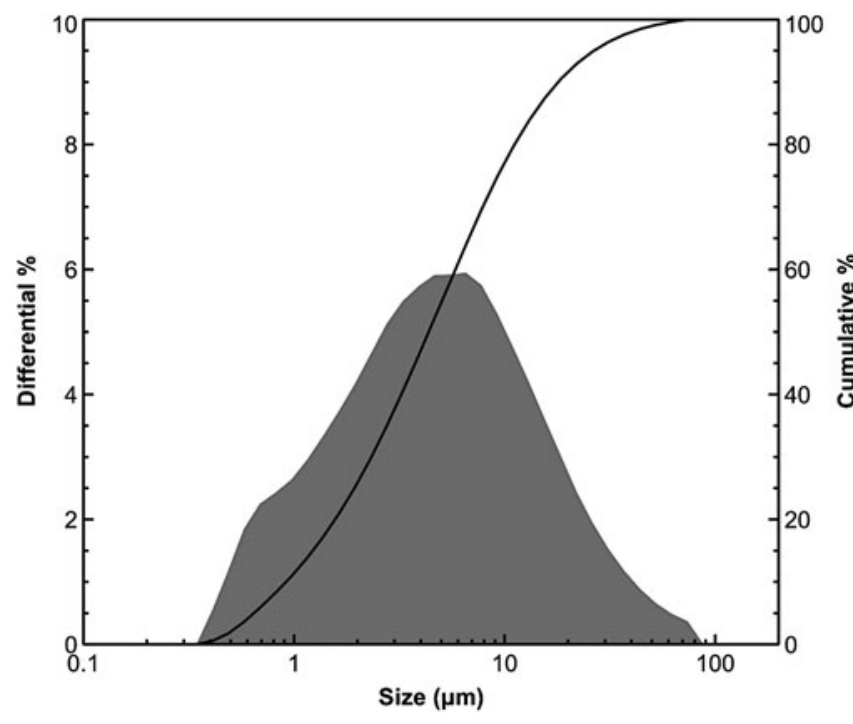

Fig. 3. Micro-granulometric analysis of the $\mathrm{C} 2$ sample.
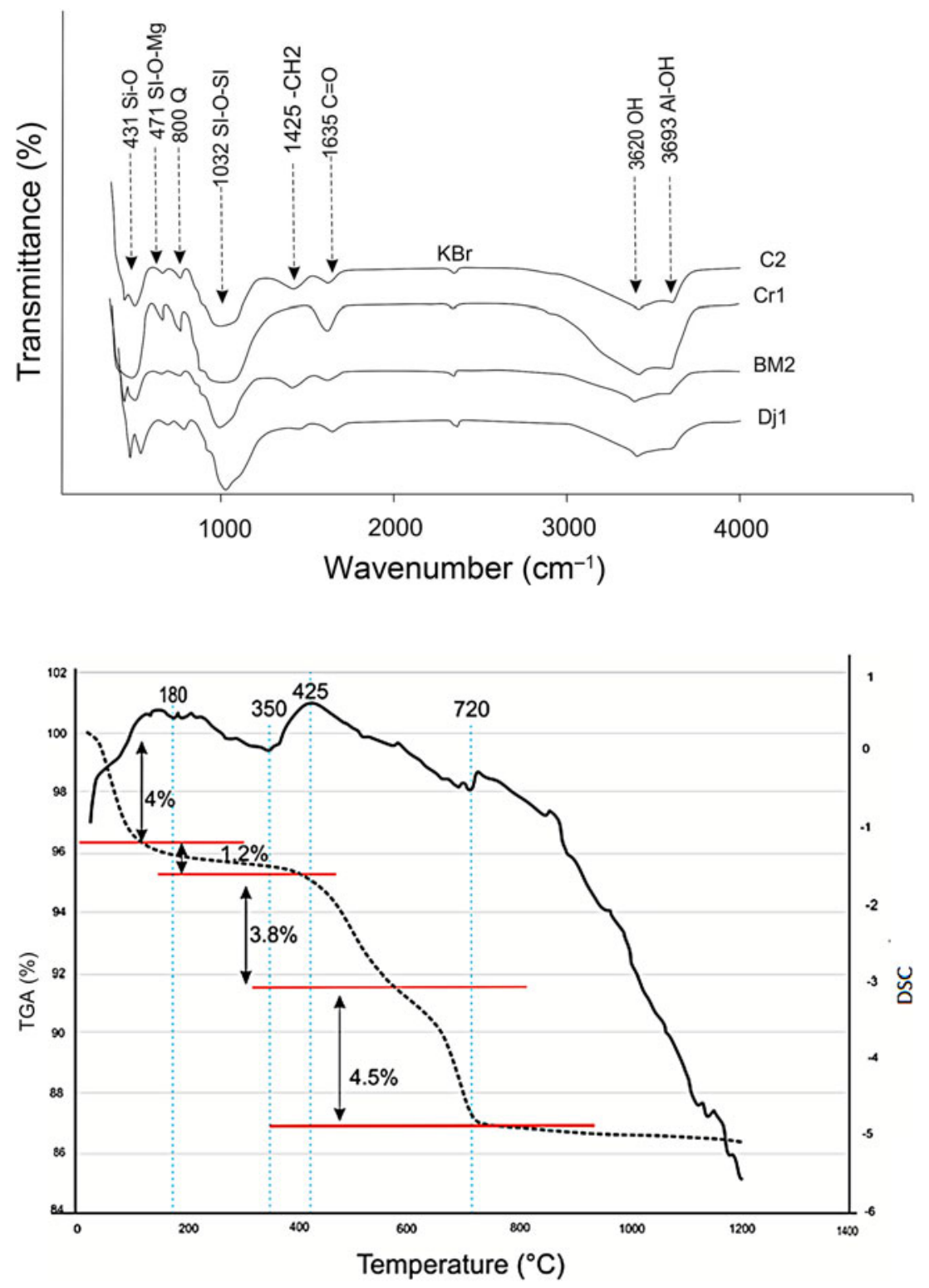

Fig. 5. FTIR spectra of the studied raw materials.

Fig. 6. TGA/DSC curves and weight loss (\%) for the C2 sample. DSC is shown by the continuous line and TGA is shown by the dotted line. 
Table 3. Mix design elemental ratios and the equivalent $\mathrm{Na}_{2} \mathrm{O}$ values of the geopolymers.

\begin{tabular}{lrrrr}
\hline & C2 & Cr1 & BM2 & Dj1 \\
\hline $\mathrm{Na}: \mathrm{Al}$ & 0.70 & 0.66 & 0.77 & 0.94 \\
$\mathrm{Si}: \mathrm{Al}$ & 2.87 & 2.81 & 3.03 & 3.85 \\
$\mathrm{H}: \mathrm{Na}$ & 29.34 & 30.14 & 29.28 & 27.81 \\
Equivalent $\mathrm{Na}_{2} \mathrm{O}$ & 8.33 & 8.60 & 8.67 & 8.63 \\
\hline
\end{tabular}

for $5 \mathrm{~h}$. Depending on the clay composition, the calcination temperature commonly varies between $600^{\circ} \mathrm{C}$ and $900^{\circ} \mathrm{C}$ (Mohammed, 2017) and enhances reactivity in an alkaline environment due to structural breakdown of clay minerals subsequent to dehydroxylation (He et al., 1995; Sabir et al., 2001; Dietel et al., 2017). Prior to mixing with the alkaline activator, the clay samples were blended with waste marble powder. The purpose of this addition was to enhance further the environmental properties of the binder by reusing a waste material that would otherwise be landfilled and to reduce the amount of alkaline activator needed due to dilution of the clay component, considering that the largest contribution to the $\mathrm{CO}_{2}$ emissions of geopolymers is associated with the alkaline activators. It has been shown that, while reducing the environmental footprint, the addition of up to $30 \%$ of waste calcium carbonate does not negatively affect the materials' properties (Valentini et al., 2020). Marble waste from Tunisian quarries has been used previously in the preparation of selfcompacting concrete (Alyousef et al., 2018). Considering that marble production in Tunisia represents an important industrial sector (Ministry of Industry and SMEs, Republic of Tunisia, 2014 ) and that up to $60 \%$ of the gross production of waste occurs during marble quarrying, polishing and processing (Montani, 2017), the addition of this waste has potential for the development of sustainable binders based on locally sourced raw materials through adopting a circular economy approach. Each sample consisted of $40.00 \mathrm{~g}$ of calcined clay, $10.00 \mathrm{~g}$ of marble powder, $11.24 \mathrm{~g}$ of sodium silicate pentahydrate powder and $24.80 \mathrm{~g}$ of water according to a one-part geopolymer approach (Luukkonen et al., 2018). The resulting elemental molar ratios are reported in Table 3.

After mixing for $3 \mathrm{~min}$, part of the paste was used to perform semi-adiabatic calorimetry measurements to assess qualitatively the early reaction kinetics. The results obtained are within the accepted limits for semi-adiabatic calorimetry (RILEM, 1997). The detailed procedure is described elsewhere (Valentini et al., 2018). The remaining paste was placed in Teflon moulds and cured at $95 \%$ relative humidity and ambient temperature for 3 days. Subsequently, the samples were demoulded and cured at ambient humidity and temperature for 7 days until compressive strength testing (Fig. 7) was carried out using a universal benchtop testing machine. After mechanical testing, the samples were kept in ethanol for $24 \mathrm{~h}$ and prepared for XRD and SEM analyses after drying. The XRD measurements were obtained using the same experimental conditions used for the unreacted samples described in the previous section. Microstructure analysis was performed on polished sections using a SEM equipped with an energy-dispersive spectrometer (EDS).

\section{Results and discussion}

\section{Phase composition and microstructure}

The disappearance of kaolinite basal and prismatic reflections was observed for the calcined samples (Fig. 8). The illite peaks were reduced in intensity, but did not disappear completely. Previous studies have shown that dehydroxylated illite persists at $800^{\circ} \mathrm{C}$ and only displays complete structural collapse at temperatures $\geq 1000^{\circ} \mathrm{C}$ (McConville \& Lea, 2005). Dolomite also disappeared in sample Dj1, and gypsum was converted to anhydrite. Hematite is observed in all of the calcined samples.

Upon reaction with the alkaline activator, alkaline carbonates (trona, thermonatrite) formed in samples Cr1 and BM2. These phases formed through the reaction of the $\mathrm{Na}^{+}$ions present in the solution with atmospheric $\mathrm{CO}_{2}$, as well as carbonate ions being derived from partial dissolution of calcite present in the waste marble. Burkeite $\left(\mathrm{Na}_{6}\left(\mathrm{CO}_{3}\right)\left(\mathrm{SO}_{4}\right)_{2}\right)$ formed in the $\mathrm{Dj} 1$ sample containing sulfates. The presence of calcite in all of the samples is due to the addition of waste calcium carbonate.

The SEM back-scatter detector images display microstructures consisting of grains of clay minerals, quartz and carbonates surrounded by a matrix of variable compactness and porosity (Fig. 9a,b). The composition of the matrix consisted of varying ratios of $\mathrm{Si}, \mathrm{Al}, \mathrm{Na}$ and $\mathrm{Ca}$, which may suggest a co-precipitation

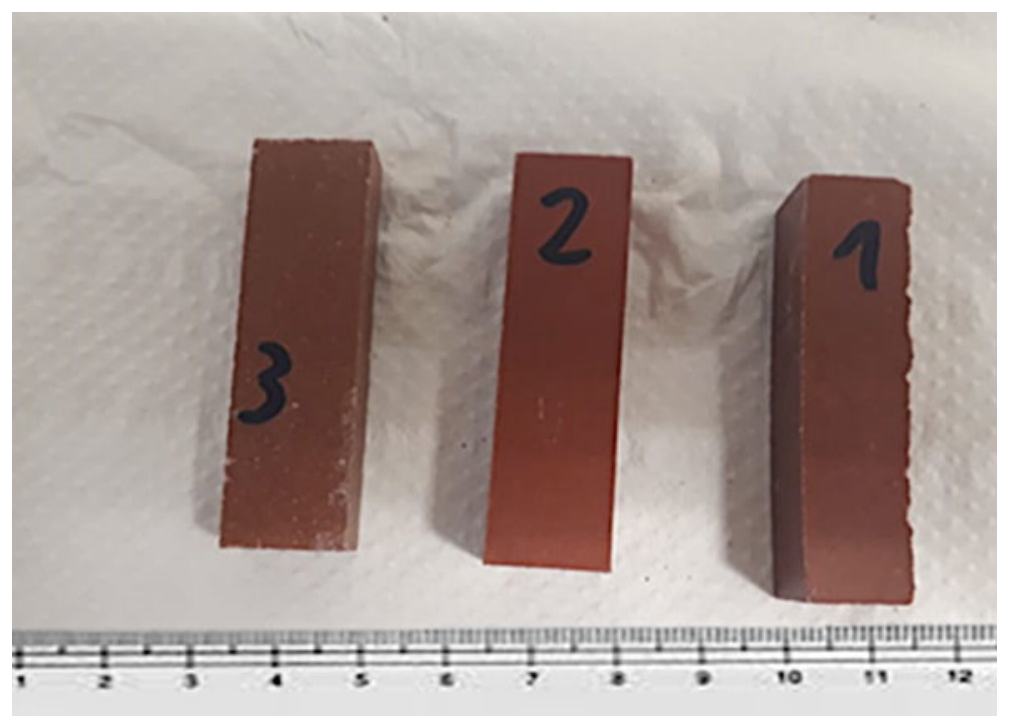



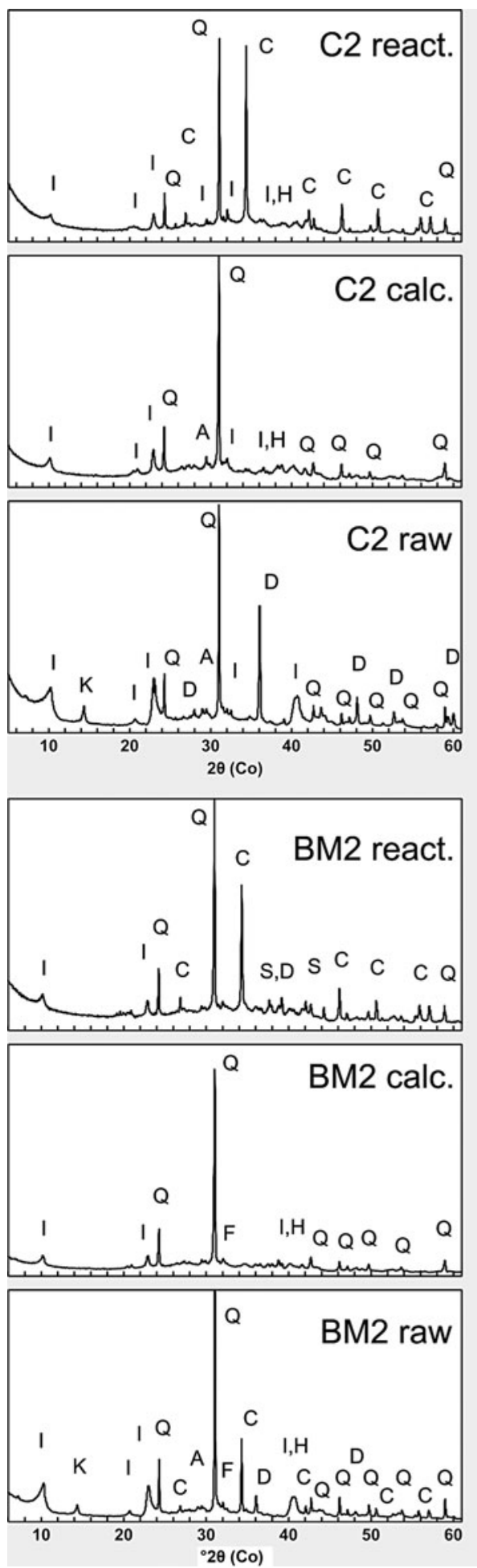
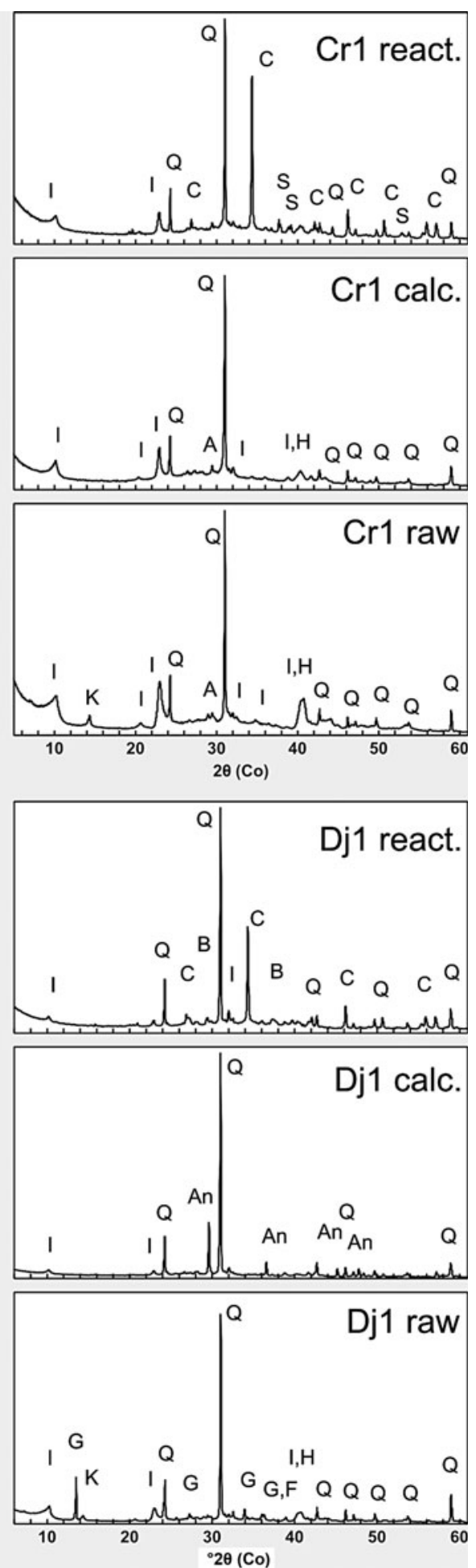

Fig. 8. XRD traces for the four clay samples before calcination (raw), after calcination (calc.) and after reaction (react.). Phase identification was based on International Centre for Diffraction Data (ICDD) and Crystallography Open Database (COD) databases. $\mathrm{I}=$ illite; $\mathrm{K}=$ kaolinite; $\mathrm{Q}=$ quartz; $\mathrm{C}=$ calcite; $\mathrm{A}=$ anatase; $\mathrm{F}$ = feldspar; $\mathrm{D}=$ dolomite; $\mathrm{H}=$ hematite; $\mathrm{G}=$ gypsum; $\mathrm{An}=$ anhydrite; $\mathrm{S}=$ sodium carbonates (trona, thermonatrite); $\mathrm{B}=$ burkeite. of Na,Al-silicate hydrate (N-A-S-H) and Ca,Al-silicate hydrate (C-A-S-H) phases (Fig. 9c,d).

\section{Strength development and reaction kinetics}

The compressive strengths of samples C2, Cr1, BM2 and Dj1 after 7 days were $25.0,11.5,10.6$ and $8.0 \mathrm{MPa}$, respectively, indicating non-refractory clays (Salah et al., 2018). Although the XRD results show that only kaolinite, which represents only a minor fraction of the total clay mineral content, became completely amorphous upon thermal treatment, samples such as C2 developed satisfactory mechanical strength. Essaidi et al. (2013, 2014) showed similar results for the illitic-kaolinitic Medenine clays calcined at $800^{\circ} \mathrm{C}$.

The early-stage reaction kinetics, as assessed by semi-adiabatic calorimetry, are shown in Figure 10. The cumulative heat release over the first $2 \mathrm{~h}$ of reaction is not correlated with the mechanical performance at 7 days, but seems to be proportional to the 

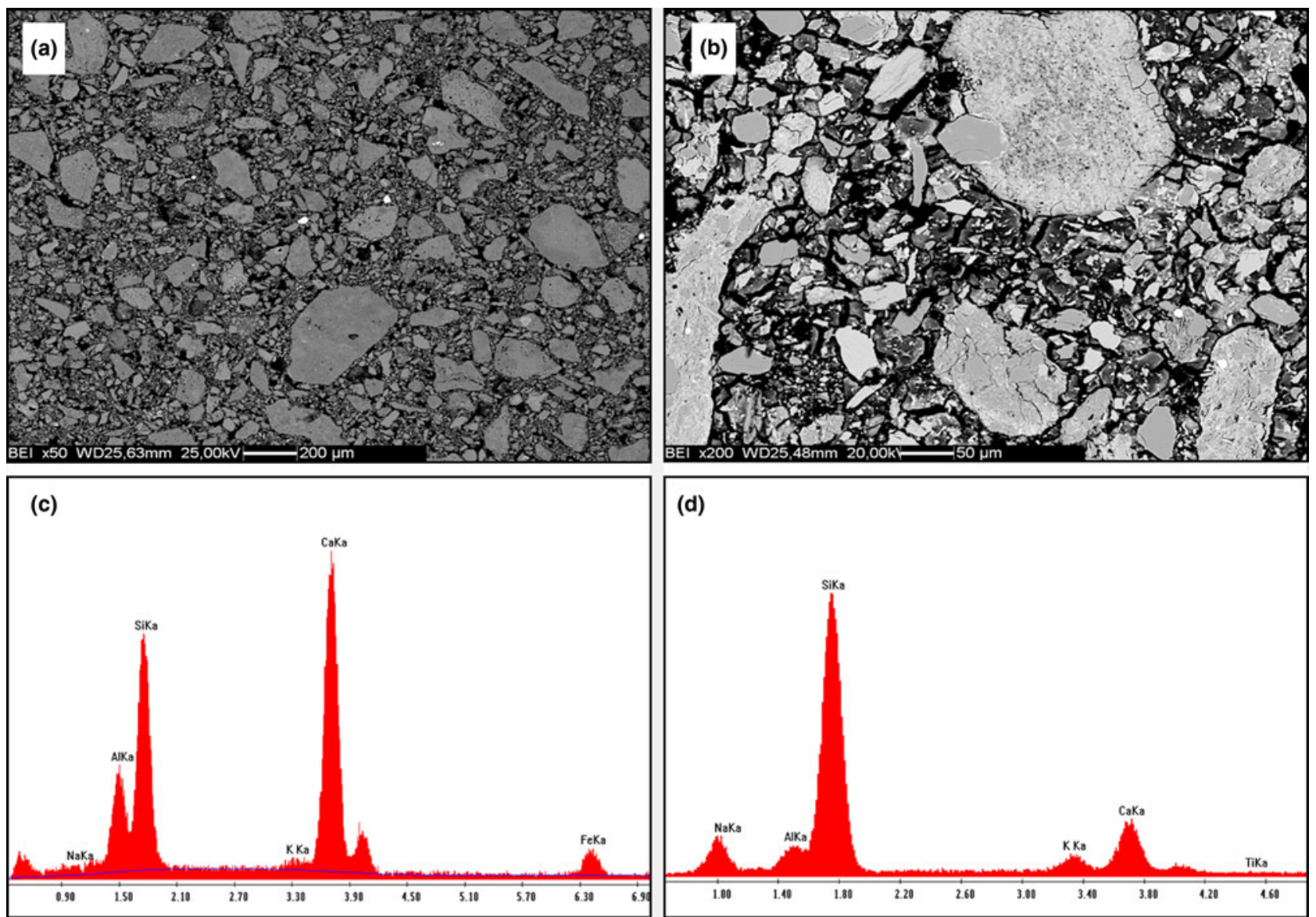

(d)

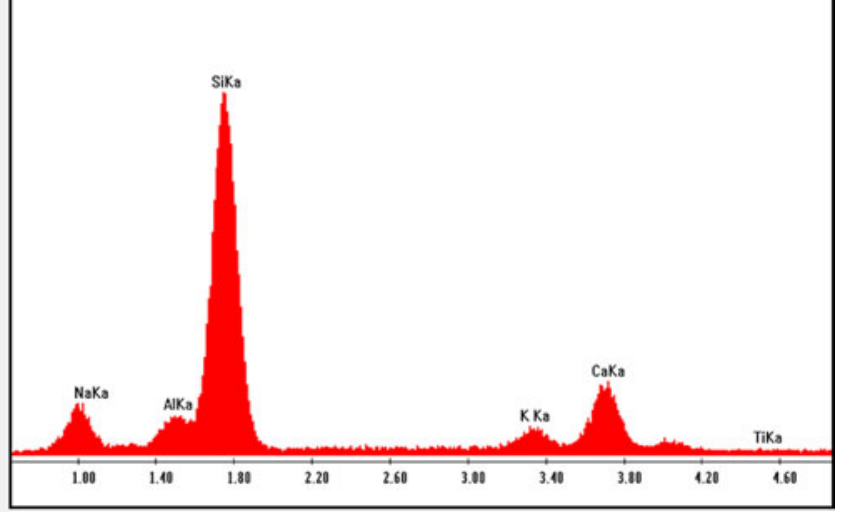

Fig. 9. SEM back-scatter detector images of reacted samples C2 (a) and Dj1 (b). (c,d) Example compositions of the sample matrices obtained using EDS analysis.

Fig. 10. Semi-adiabatic calorimetry heat release curve (differential curve over the first 10 min displayed in the inset).

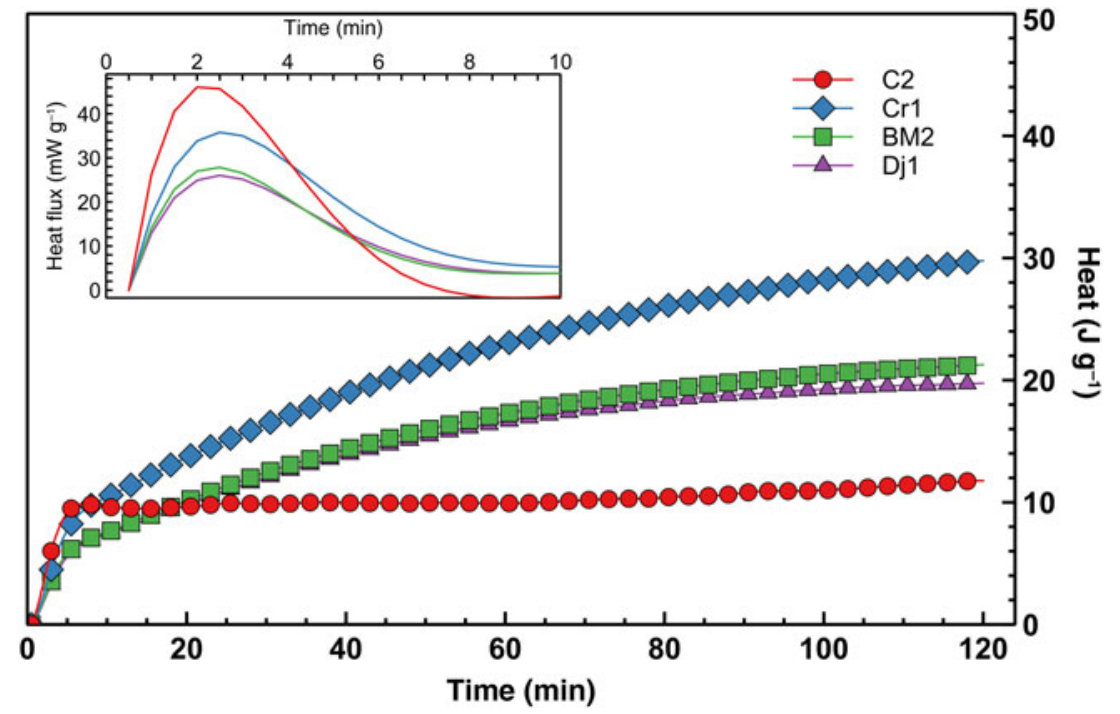

dissolution, facilitated by the temperature increase that was induced by the dissolution of the alkaline activator. Both the early heat release and compressive strength are proportional to the amount of kaolinite in the clay mineral fraction (Fig. 11), suggesting that the kaolinite:illite ratio exerts primary control over the development of a stiff matrix due to the total structural 

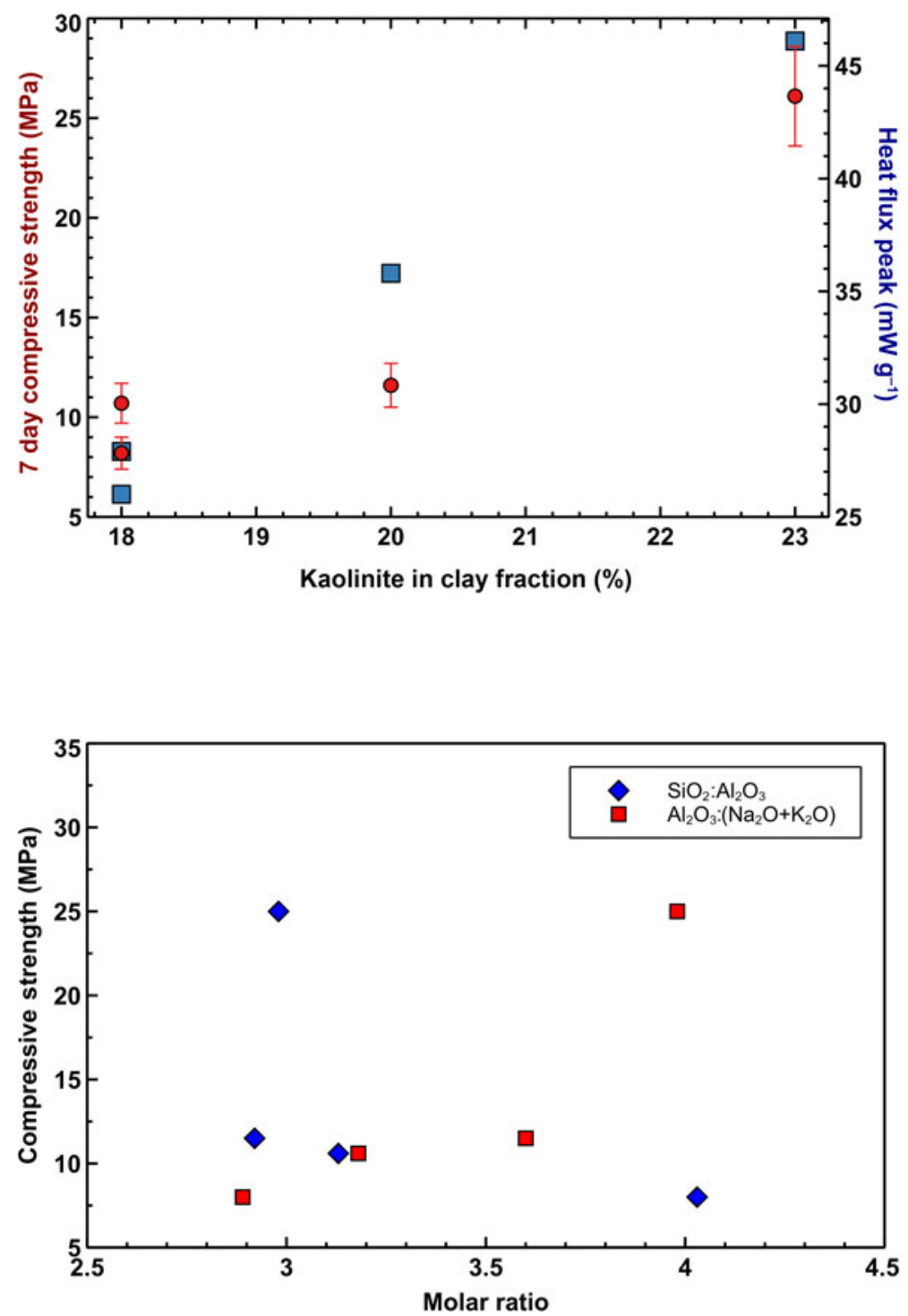

Fig. 11. Kaolinite percentage in the clay fraction vs compressive strength (red circles) and vs magnitude of the peak in the differential heat release curve (blue squares). collapse of kaolinite with respect to illite resulting in better reactivity. Nevertheless, although samples $\mathrm{C} 2$ and $\mathrm{Cr} 1$ have similar kaolinite contents, the former displays significantly greater compressive strength. This might be due to the thermal decomposition of the dolomite present in sample $\mathrm{C} 2$ that leads to the formation of $\mathrm{MgO}$, which contributes to strength development, although its presence is not easily detectable in the XRD pattern. Previous studies have suggested that the presence of $\mathrm{MgO}$ in geopolymers is beneficial to strength development due to the mitigation of shrinkage (Li et al., 2019).

The mechanical results are correlated with the $\mathrm{SiO}_{2}: \mathrm{Al}_{2} \mathrm{O}_{3}$ and $\mathrm{Al}_{2} \mathrm{O}_{3}:\left(\mathrm{N}_{2} \mathrm{O}+\mathrm{K}_{2} \mathrm{O}\right)$ ratios. The strength of the hardened pastes decreases slightly with increasing $\mathrm{SiO}_{2}: \mathrm{Al}_{2} \mathrm{O}_{3}$ ratios and increases with increasing $\mathrm{Al}_{2} \mathrm{O}_{3}:\left(\mathrm{N}_{2} \mathrm{O}+\mathrm{K}_{2} \mathrm{O}\right)$ ratios (Fig. 12) (Keppert et al., 2018).

\section{Conclusion}

This study yielded satisfactory results for geopolymeric binders based on natural clays collected from the Kebili region of southern Tunisia, consisting of clay fractions dominated by illite and lesser amounts of kaolinite. Although the kaolinite contents of these clays are $<30 \%$, these materials showed promising mechanical performance upon thermal treatment and alkali activation, reaching mechanical strengths of $25 \mathrm{MPa}$ after 1 week for sample C2, which contains significant amounts of dolomite in addition to illite and kaolinite. The addition of waste marble was not detrimental to mechanical strength, while being beneficial in terms of environmental performance. Partial dissolution of the calcite present in waste marble seems to lead to the co-precipitation of $\mathrm{N}-\mathrm{A}-\mathrm{S}-\mathrm{H}$ and $\mathrm{C}-\mathrm{A}-\mathrm{S}-\mathrm{H}$ products, as suggested by the significant amounts of $\mathrm{Ca}$ present in the matrix.

Mechanical results were discussed in terms of the $\mathrm{SiO}_{2}: \mathrm{Al}_{2} \mathrm{O}_{3}$ and $\mathrm{Al}_{2} \mathrm{O}_{3}:\left(\mathrm{N}_{2} \mathrm{O}+\mathrm{K}_{2} \mathrm{O}\right)$ ratios. These results indicate that the higher compressive strength matches with lower $\mathrm{SiO}_{2}: \mathrm{Al}_{2} \mathrm{O}_{3}$ ratios and higher $\mathrm{Al}_{2} \mathrm{O}_{3}:\left(\mathrm{N}_{2} \mathrm{O}+\mathrm{K}_{2} \mathrm{O}\right)$ ratios, which reflects the kaolinite content before alkali activation.

This study shows that careful selection of raw materials based on mineralogical and chemical analysis is fundamental for the achievement of suitable material properties. Additional studies will be necessary to assess the suitability of the Kebili clays for the industrial production of sustainable building materials by 
optimization of the mix design as well as of other properties, such as workability and durability.

Acknowledgements. The authors thank all of the laboratory staff in the institutions where the analyses were carried out: Inter-Departmental Research Centre for the Study of Cement Materials and Hydraulic Binders (Padua, Italy), National Office of Mines (ONM; Tunisia) and the National Centre of Research in Materials Sciences (CNRSM; Tunisia).

\section{References}

Abbes A. \& Tlig S. (1991) Tectonique précoce et sédimentation de la série crétacée dans le Bassin des Chotts (Tunisie du Sud). Géologie Méditerranéenne, 18, 149-161.

Allahverdi A. \& Kani E.N. (2009) Construction wastes as raw materials for geopolymer binders. International Journal of Civil Engineering, 7, 154-160.

Alyousef R., Benjeddou O., Khadimallah M.A., Mohamed A.M. \& Soussi C. (2018) Study of the effects of marble powder amount on the selfcompacting concretes properties by microstructure analysis on cementmarble powder pastes. Advances in Civil Engineering, 2018, 6018613.

Anis Z., Wissem G., Riheb H., Biswajeet P. \& Essghaier G.M. (2019) Effects of clay properties in the landslides genesis in flysch massif: case study of AinDraham, north western Tunisia. Journal of African Earth Sciences, 151, 146-152.

Babaee M. \& Castel A. (2016) Chloride-induced corrosion of reinforcement in low-calcium fly ash-based geopolymer concrete. Cement and Concrete Research, 88, 96-107.

Ben Youssef M. \& Peybernes B. (1986) Données micropaléontologiques nouvelles sur le Crétacé inférieur marin du Sud Tunisien. Journal of African Earth Sciences, 5, 217-231.

Bennour A., Mahmoudi S., Srasra E., Boussen S. \& Htira N. (2015a) Composition, firing behavior and ceramic properties of the Sejnène clays (northwest Tunisia). Applied Clay Science, 115, 30-38.

Bennour A., Mahmoudi S., Srasra E., Hatira N., Boussen S., Ouaja M. \& Zargouni F. (2015b) Identification and traditional ceramic application of clays from the Chouamekh region in south-eastern Tunisia. Applied Clay Science, 118, 212-220.

Boussen S., Sghaier D., Chaabani F., Jamoussi B. \& Bennour A. (2016) Characteristics and industrial application of the Lower Cretaceous clay deposits (Bouhedma Formation), southeast Tunisia: potential use for the manufacturing of ceramic tiles and bricks. Applied Clay Science, 123, $210-221$.

Brew D.R.M. \& MacKenzie K.J.D. (2007) Geopolymer synthesis using silica fume and sodium aluminate. Journal of Materials Science, 42, 3990-3993.

Carvalho J., Carvalho P., Pinto A.T. \& Labrincha J.A. (2008) Activation of mixtures of natural clay and glass cullet rejects. Clay Minerals, 43, 657-667.

Casagrande A. (1947) Plasticity chart for the classification of cohesive soils. Transactions of the American Society of Civil Engineering, 783, 811.

Celik H. (2010) Technological characterization and industrial application of two Turkish clays for the ceramic industry. Applied Clay Science, 50, $245-254$.

Chakraborty A.K. (2014) Phase Transformation of Kaolinite Clay. Springer India, New Delhi, India, 360 pp.

Cui X.M., Zheng G.J., Han Y.C., Su F. \& Zhou J. (2008) A study on electrical conductivity of chemosynthetic $\mathrm{Al}_{2} \mathrm{O}_{3}-2 \mathrm{SiO}_{2}$ geoploymer materials. Journal Power Sources, 184, 652-656.

Davidovits J. (1988) Geopolymer chemistry and properties. Geopolymer, 88, 25-48.

Davidovits J. (2011) Geopolymer Chemistry and Applications, 3rd edition. Institut Geopolymere, Saint-Quentin, France.

Dietel J., Warr L.N., Bertmer M., Steudel A., Grathoff G.H. \& Emmerich K. (2017) The importance of specific surface area in the geopolymerization of heated illitic clay. Applied Clay Science, 139, 99-107.

Ding Y., Dai J.G. \& Shi C.J. (2016) Mechanical properties of alkali- activated concrete: a state-of-the-art review. Construction and Building Materials, 127, 68-79.
Diop M.B. \& Grutzeck M.W. (2008) Low temperature process to create brick. Construction and Building Materials, 22, 1114-1121.

Duxson P.S.W.M., Mallicoat S.W., Lukey G.C., Kriven W.M. \& Van Deventer J.S. (2007) The effect of alkali and Si/Al ratio on the development of mechanical properties of metakaolin-based geopolymers. Colloids and Surfaces A: Physicochemical and Engineering Aspects, 29, 8-20.

Essaidi N., Samet B., Baklouti S. \& Rossignol S. (2013) Effect of calcination temperature of Tunisian clays on the properties of geopolymers. Ceramics, 57, 251-257.

Essaidi N., Samet B., Baklouti S. \& Rossignol S. (2014) Feasibility of producing geopolymers from two different Tunisian clays before and after calcination at various temperatures. Applied Clay Science, 88, 221-227.

Farmer V.C. (1974) The Layers Silicates. The Infrared Spectra of Minerals Monograph 4. Mineralogical Society, London, UK, pp. 331-363.

Fernandez R., Martirena F. \& Scrivener K.L. (2011) The origin of the pozzolanic activity of calcined clay minerals: a comparison between kaolinite, illite and montmorillonite. Cement and Concrete Research, 41, 113-122.

Fernández-Jiménez A., Pastor J.Y., Martín A. \& Palomo A. (2010) High-temperature resistance in alkali-activated cement. Journal of the American Ceramic Society, 93, 3411-3417.

Ferrari S. \& Gualtieri A.F. (2006) The use of illitic clays in the production stoneware tile ceramics. Applied Clay Science, 32, 73-81.

Garg N. \& Skibsted J. (2014) Thermal activation of a pure montmorillonite clay and its reactivity in cementitious systems. Journal of Physical Chemistry C, 118, 11464-11477.

Ghanmi M. \& Potfaj M. (1987) Carte géologique de la Tunisie au 1/100 000. Feuille $n^{\circ} 82$, Oglet Marteba. Office National des Mines de Tunisie, Tunis, Tunisia.

Ghanmi M. \& Potfaj M. (1991) Données stratigraphiques sur la chaîne de Tebaga de Kebili Jebel Aziza (Tunisie méridionale): conséquences paléogéographiques et tectoniques. Notes du Service Géologique Tunisie, 58, 21-28.

Glukovsky V.D. (1959) Gruntosilikaty. Grosstrojizdat, Kiev, Ukraine.

Grabowska-Olszewska B. (2003) Modelling physical properties of mixtures of clays example of a two-component mixture of kaolinite and montmorillonite. Applied Clay Science, 22, 251-259.

Guo Y. \& Rockstraw D.A. (2006) Physical and chemical properties of carbons synthesized from xylan, cellulose, and Kraft lignin by $\mathrm{H}_{3} \mathrm{PO}_{4}$ activation. Carbon, 44, 1464-1475.

Hajjaji M., Kacim S., Alami A., El Bouadili A. \& El Mountassir M. (2001) Chemical and mineralogical characterization of a clay taken from the Moroccan Meseta and a study of the interaction between its fine fraction and methylene blue. Applied Clay Science, 20, 1-12.

Hajjaji W., Moussi B., Hachani M., Medhioub M., Lopez-Galindo A., Rocha F. et al. (2010) The potential use of Tithonian-Barremian detrital deposits from central Tunisia as raw materials for ceramic tiles and pigments. Applied Clay Science, 48, 552-560.

Hammami-Ben Zaied F., Abidi R., Slim-Shimi N. \& Somarin A.K. (2015) Potentiality of clay raw materials from grain the ceramic industry. Applied Clay Science, 112, 1-9.

Handke M. \& Mozgawa W. (1993) Vibrational spectroscopy of the amorphous silicates. Vibrational Spectroscopy, 5, 75-84.

He C., Osbaeck B. \& Makovicky E. (1995) Pozzolanic reactions of six principal clay minerals: activation, reactivity assessments and technological effects. Cement and Concrete Research, 25, 1691-1702.

Hollanders S., Adriaens R., Skibsted J., Cizer Ö. \& Elsen J. (2016) Pozzolanic reactivity of pure calcined clays. Applied Clay Science, 132, 552-560.

Hounsi A.D., Lecomte-Nana G.L., Djétéli G. \& Blanchart P. (2013) Kaolin-based geopolymers: effect of mechanical activation and curing process. Construction and Building Materials, 42, 105-113.

Keppert M., Vejmelková E., Bezdička P., Doleželová M., Čáchová M. Scheinherrová L. et al. (2018) Red-clay ceramic powders as geopolymer precursors: consideration of amorphous portion and $\mathrm{CaO}$ content. Applied Clay Science, 161, 82-89.

LCPC (1987) Limites d'Atterberg, limite de liquidité, limite de plasticité. Méthode d'essai $n^{\circ} 19$. Laboratoire Central des Ponts et Chaussées, Paris, France, $26 \mathrm{pp}$. 
Li Z., Zhang W., Wang R., Chen F., Jia X. \& Cong P. (2019) Effects of reactive $\mathrm{MgO}$ on the reaction process of geopolymer. Materials, 12, 526.

Liebau F. (1985) Structural Chemistry of Silicates: Structure, Bonding and Classification. Springer Science \& Business Media, Berlin, Germany.

Luukkonen T., Abdollahnejad Z., Yliniemi J., Kinnunen P. \& Illikainen M. (2018) One-part alkali-activated materials: a review. Cement and Concrete Research, 103, 21-34.

M’barek-Jemaï M.B., Sdiri A., Salah I.B., Aissa L.B., Bouaziz S. \& Duplay J. (2017) Geological and technological characterization of the Late JurassicEarly Cretaceous clay deposits (Jebel Ammar, northeastern Tunisia) for ceramic industry. Journal of African Earth Sciences, 129, 282-290.

MacKenzie K.J.D. (2009) Utilisation of non-thermally activated clays in the production of geopolymers. Pp. 296-316 in: Geopolymers: Structure, Processing, Properties and Industrial Applications (J.L. Provis \& J.S.J. Van Deventer, editors). Elsevier, Amsterdam, The Netherlands.

Madejová J. (2003) FTIR techniques in clay mineral studies. Vibrational Spectroscopy, 31, 1-10.

Mahmoudi S., Bennour A., Meguebli A., Srasra E. \& Zargouni F. (2016) Characterization and traditional ceramic application of clays from the Douiret region in South Tunisia. Applied Clay Science, 127, 78-87.

Marsh A., Heath A., Patureau P., Evernden M. \& Walker P. (2018) Alkali activation behavior of un-calcined montmorillonite and illite clay minerals. Applied Clay Science, 166, 250-261.

McConville C.J. \& Lee W.E. (2005) Microstructural development on firing illite and smectite clays compared with that in kaolinite. Journal of the American Ceramic Society, 88, 2267-2276.

Merabtene M., Kacimi L. \& Clastres P. (2019) Elaboration of geopolymer binders from poor kaolin and dam sludge waste. Heliyon, 5, e01938.

Ministry of Industry and SMEs, Republic of Tunisia (2014) CEPI Brief No. 6: Strategic positioning study of the marble branch. Available online: http:// www.tunisianindustry.nat.tn/en/download/CEPI/IMCCV02.pdf

Mkaouar S., Maherzi W., Pizette P., Zaitan H. \& Benzina M. (2019) A comparative study of natural Tunisian clay types in the formulation of compacted earth blocks. Journal of African Earth Sciences, 160, 103620.

Mohammed S. (2017) Processing, effect and reactivity assessment of artificial pozzolans obtained from clays and clay wastes: a review. Construction and Building Materials, 140, 10-19.

Montani C. (2017) XXVIII RapportoMarmo e Pietrenel Mondo 2017 (XXVIII World Marble and Stones Report 2017). Aldus Casa di Edizione, Carrara, Italy, $250 \mathrm{pp}$.

Mozgawa W., Sitarz M. \& Rokita M. (1999) Spectroscopic studies of different aluminosilicate structures. Journal of Molecular Structure, 511, 251-257.

Nayak P.S. \& Singh B.K. (2007) Instrumental characterization of clay by XRF, XRD and FTIR. Bulletin of Materials Science, 30, 235-238.

Petit S. (2006) Fourier transform infrared spectroscopy. Pp. 909-918 in: Handbook of Clay Science (F. Bergaya and G. Lagaly, editors). Developments in Clay Science, 5, Elsevier, Amsterdam, The Netherlands.

Provis J.L. (2014) Geopolymers and other alkali activated materials: why, how, and what? Materials and Structures, 47, 11-25.
Rabia M.C. (1984) Etude géologique de la région des Chotts par télédétection spatiale, détection de la radioactivité naturelle et analyse hydrogéochimique. Thèse de troisième cycle, Université de Bordeaux, France, 190 pp.

Reig L., Tashima M.M., Borrachero M.V., Monzó J., Cheeseman C.R. \& Payá J. (2013) Properties and microstructure of alkali-activated red clay brick waste. Construction and Building Materials, 43, 98-106.

RILEM (1997) 119-TCE: avoidance of thermal cracking in concrete at early ages. Materials and Structures, 30, 1-464.

Sabir B.B., Wild S. \& Bai J. (2001) Metakaolin and calcined clays as pozzolans for concrete: a review. Cement and Concrete Composites, 23, 441-454.

Salah I.B., Sdiri A., Jemai M.B.M.B. \& Boughdiri M. (2018) Potential use of the lower Cretaceous clay (Kef area, northwestern Tunisia) as raw material to supply ceramic industry. Applied Clay Science, 161, 151-162.

Sdiri A., Higashi T., Hatta T., Jamoussi F. \& Tase N. (2010) Mineralogical and spectroscopic characterization and potential environmental use of limestone from the Abiod formation, Tunisia. Environmental Earth Sciences, 61, $1275-1287$.

Selmani S., Essaidi N., Gouny F., Bouaziz S., Joussein E., Driss A. \& Rossignol S. (2015) Physical-chemical characterization of Tunisian clays for the synthesis of geopolymers materials. Journal of African Earth Sciences, 103, 113-120.

Shaqour F., Ismeik M. \& Esaifan M. (2017) Alkali activation of natural clay using a $\mathrm{Ca}(\mathrm{OH})_{2} / \mathrm{Na}_{2} \mathrm{CO}_{3}$ alkaline mixture. Clay Minerals, 52, 485-496.

Sivapullaiah P.V., Prasad B.G. \& Allam M.M. (2008) Methylene blue surface area method to correlate with specific soil properties. Geotechnical Testing Journal, 31, 503-512.

Srasra E., Bergaya F. \& Fripiat J.J. (1994) Infrared spectroscopy study of tetrahedral and octahedral substitutions in an interstratified illite-smectite clay. Clays and Clay Minerals, 42, 237-241.

Tironi A., Trezza M.A., Scian A.N. \& Irassar E.F. (2013) Assessment of pozzolanic activity of different calcined clays. Cement and Concrete Composites, 37, 319-327.

Valentini L., Contessi S., Dalconi M. C., Zorzi F. \& Garbin E. (2018) Alkali-activated calcined smectite clay blended with waste calcium carbonate as a low-carbon binder. Journal of Cleaner Production, 184, $41-49$.

Valentini L., Mascarin L., Ez-zaki H., Bediako M., Mwiti Marangu J. \& Bellotto M. (2020) Use of waste calcium carbonate in sustainable cement. Presented at: RILEM Spring Convention 2020, Guimaraes, Portugal, 10-14 March 2020.

van der Marel H.W. \& Beutelspacher H. (1976) Atlas of Infrared Spectroscopy of Clay Minerals and Their Admixtures. Elsevier, Amsterdam, The Netherlands, 396 pp.

Xu H. \& Van Deventer J. S. (2003) The effect of alkali metals on the formation of geopolymeric gels from alkali-feldspars. Colloids and Surfaces A: Physicochemical and Engineering Aspects, 216, 27-44.

Zhang Y.S., Sun W. \& Li Z.J. (2010) Composition design and microstructural characterization of calcined kaolin-based geopolymer cement. Applied Clay Science, 47, 271-275 